\author{
Jovana Galjak, Jelena Djokic, Srdjan Jovic* \\ ${ }^{1}$ University of Priština, Faculty of Technical Sciences, \\ Kosovska Mitrovica, Serbia
}

\author{
Scientific paper \\ ISSN 0351-9465, E-ISSN 2466-2585 \\ UDC:379.844/.845 \\ doi:10.5937/zasmat1804495G
}

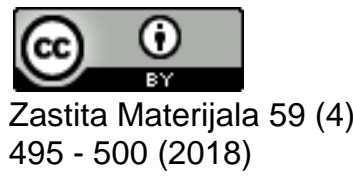

\title{
Prediction of visitors' thermal comfort in open urban areas
}

\begin{abstract}
Thermal sensation of visitors could be important indicator for urban spaces based on physiological, psychological and behavioural conditions of the visitors. Therefore in this article thermal comfort of the visitors in open urban spaces was investigated. For such a purpose physical data and questionnaire study were used. In order to estimate the optimal conditions in the open urban areas there is need to perform prediction of the thermal comfort and thermal comfort in the areas. The prediction results could be used for optimal arrangement in the open urban areas based on thermal comfort of the visitors. Results of three methods were compares and analysed. The methods are based on artificial intelligence principle.
\end{abstract}

Keywords: Thermal comfort; Urban square; Neural network; Microclimatic.

\section{INTRODUCTION}

Rapid development of urban areas requires also acceptable thermal conform of visitors as well. There is need to investigate the thermal comfort based on the microclimatic environmental factors. There are different factors which could impact the thermal conform of the visitors. The factors could be social, cultural and recreational activities of the visitors. Thus there is need to create a methodology which will be based on all aspect of thermal comfort.

Psychological and sociocultural processes are important in assessment of thermal comfort [1]. One of the greatest environmental challenges for the sustainability of future cities is the mitigation of the urban heat island phenomenon and thus, improvement of outdoor comfort conditions for people [2]. There is need to bridge the gap between urban climatology and urban design in coastal temperate climate cities of developing countries [3]. Urban parks were measured to be thermally uncomfortable, but were perceived to be thermally comfortable [4].

\footnotetext{
${ }^{*}$ Corresponding author: Srdjan Jovic

E-mail: srdjanjovic2016@hotmail.com

Paper received: 24. 08. 2018.

Paper accepted: 12. 09. 2018.

Paper is available on the website: www.idk.org.rs/journal
}

Economic development of city could be improved by well-designed urban space could attract more visitors and to enhance their mood and behaviour and facilitate social interactions [5]. Also extreme weather conditions need to be counted during designing of open urban spaces since the weather could be vulnerable in the spaces [6]. Global warming factor needs to be included as well in the modelling of urban spaces [7].

Results in article [8] were shown there are relationship between indoor and outdoor thermal sensation. There are several investigations of the indoor thermal confirm but there are no similar investigations for open urban spaces [9-16]. Thermal comfort is investigated in urban canons and tropic zones [15-22].

In the study thermal comfort of visitors in open urban areas are investigated based on artificial intelligence methods [23-32]. The thermal comfort are analysed based on four parameters: physiologically predicted mean vote (PMV), the equivalent temperature (PET), the standard effective temperature (SET). Predictive models are created for the outputs with an advances algorithm based on artificial intelligence methods. As the input factors microclimatic parameters are used and questionnaire survey is performed of the visitors about their thermal comfort. 


\section{METHODOLOGY}

\subsection{Experimental measurements of thermal comfort in open urban area}

Urban locations in Serbia are analysed and corresponding data are acquired. The measurements are performed on the field for one whole year to cover all microclimatic and climatic conditions. The parameters which are measured are: air temperature $\left(T_{a}\right)$, globe temperature $\left(T_{g}\right)$, relative humidity $(R H)$, globe radiation $\left(R_{s}\right)$, wind speed $\left(\mathrm{W}_{\mathrm{s}}\right)$ and wind direction $\left(\mathrm{W}_{\text {dir }}\right)$.

There are also questionnaire survey of the visitors on the open urban areas which is also conducted. The survey is based on demographic information, overall conform feeling, reasons to be there, visitors' behaviour. These input factors for the survey are: location, activity, age group, gender and locality.

Input factor "location" is based on the visitors' location in the urban area. There are four locations which are identified. The first location with open space with covering roofs. The second location is fully shaded open urban area. The third location is on the plants area. The fourth location is on the open urban space or urban square.

Input factor "activity" is based on visitors' activity on the open urban space. There are four activities in the study: sedentary, standing, walking, riding a motorcycle, exercising, riding a bicycle.

Input factor "age group" is based on the visitors' age as follows: child, teen, 18-24, 25-43, 45-54, 55-64 and more than 65.

Input factor "gender" has two numerical values based on the visitors' gender. Also the input factor "locality" has two numerical values for local visitors and for tourist visitors.

There are four outputs which are used in the study. These parameters represents the thermal comfort in the open urban area. The outputs are calculated by RayMan model [33].

\subsection{Computational modelling by artificial intelligence methods}

The first methodology is based on neural network (NN) principle. The acquired input/output data pairs are used for NN training and testing purpose. NN is capable to solve relationship of the highly nonlinear data like thermal comfort data. As training algorithm for the $\mathrm{NN}$, extreme learning machine (ELM) $[34,35]$ is used. Although there are many different training algorithms for the $\mathrm{NN}$, extreme learning machine us used since the ELM is faster than traditional training method like backpropagation algorithm. By using ELM more reliable generalization performances could be observed and training process is faster than backpropagation (BP) algorithm [36]. ELM training algorithm uses single feed forward neural networks. Basic principle of the ELM training procedure is determining of random input weights of the NN. In such a way training procedure is more relaxed and therefore there is need less time.

The predictive results of the NN with ELM training algorithm are then compared with computational methodology based on artificial intelligence like genetic programming (GP). Also as comparative results NN with ELM is compares with $\mathrm{NN}$ with $\mathrm{BP}$ training algorithm.

The predictive results of the applied methodologies are compared by three statistical indicators: mean square error (RMSE), the coefficient of determination (R2), and the Pearson correlation coefficient $(r)$.

\section{RESULTS}

Figures 1-3 shows the predictive performances of the thermal comfort with the three methods based on the given inputs. Figure 2 shows the predictive results by NN with ELM for:

- Equivalent temperature (PET)

- Physiologically predicted mean vote (PMV)

- Standard effective temperature (SET)

One can note that the NN with ELM has the best predictive performances for the PET prediction according to the coefficient of determination. Based on the results in Figure 2 and 3 one can conclude that the NN with ELM has the better predictive performances for thermal comfort than NN with BP and GP results.

Table 1 shows the comparative results of the three methods based on the three statistical indicators. NN with ELM outperform the other two approaches based on the all statistical indicators. Also one can note that the NN with ELM has high prediction accuracy for the thermal comfort. In other words RMSE values should be smaller and $\mathrm{R} 2$ and $\mathrm{r}$ should be closer to 1 in order to be more precise. Based on R2 coefficient one can see that ELM approach has strongest correlation since R2 values are higher than 0.95 . 


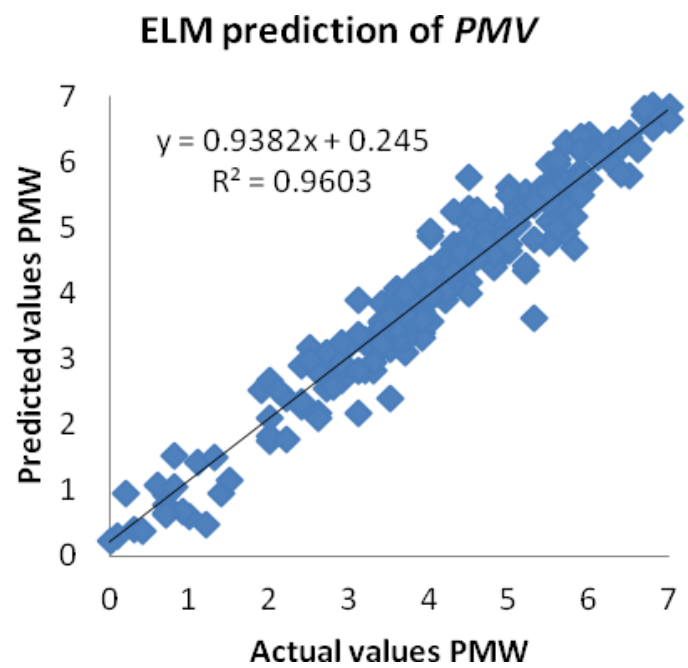

ELM prediction of $P E T$

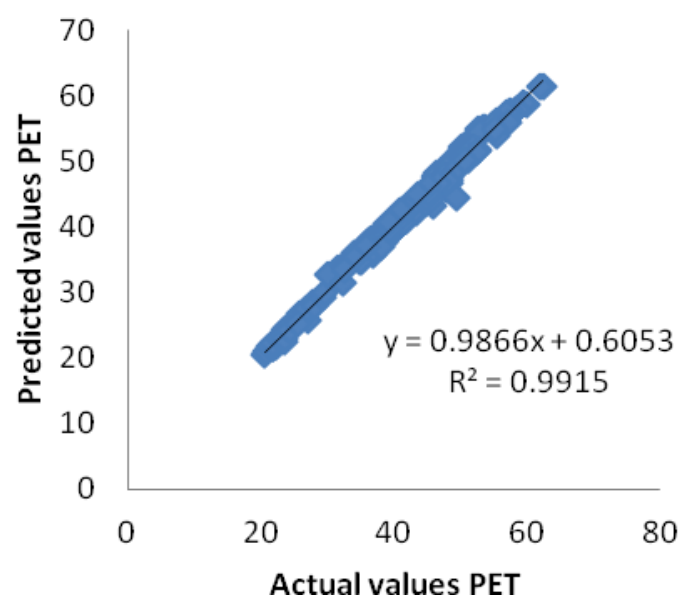

ELM prediction of SET

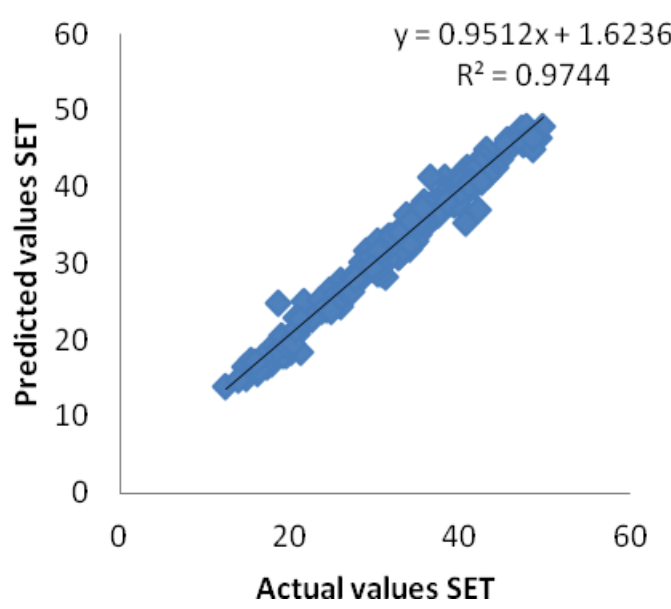

Figure 1. NN with ELM predictive results for thermal comfort parameters

Slika 1. Neuronska mreža sa ELM principom za predikciju parametra termalnog komfora

\section{GP prediction of $P M V$}

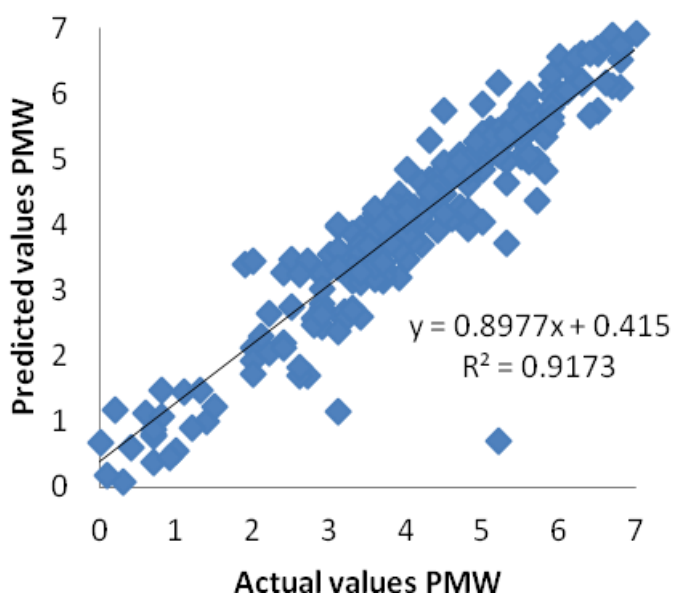

GP prediction of PET

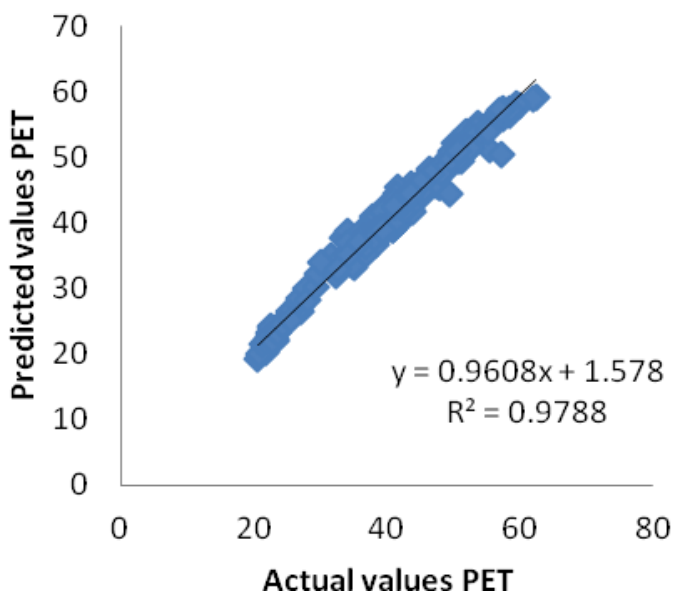

GP prediction of SET

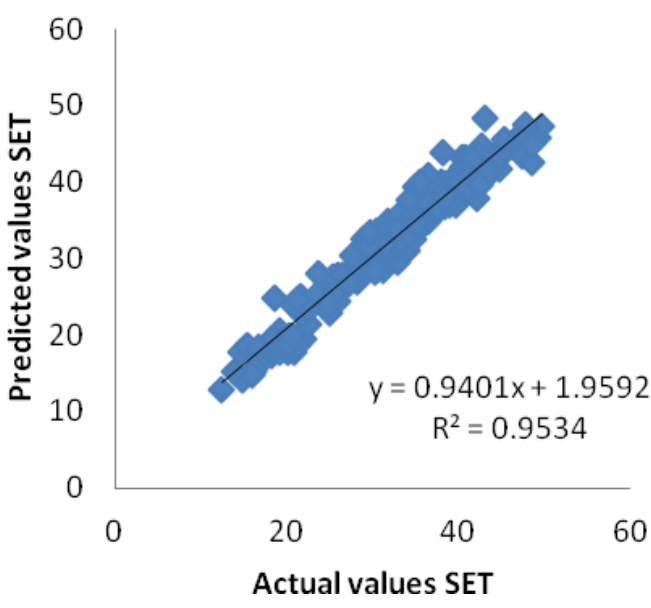

Figure 2. GP predictive results for thermal comfort parameters

Slika 2. GP metoda za predikciju parametra termalnog komfora 


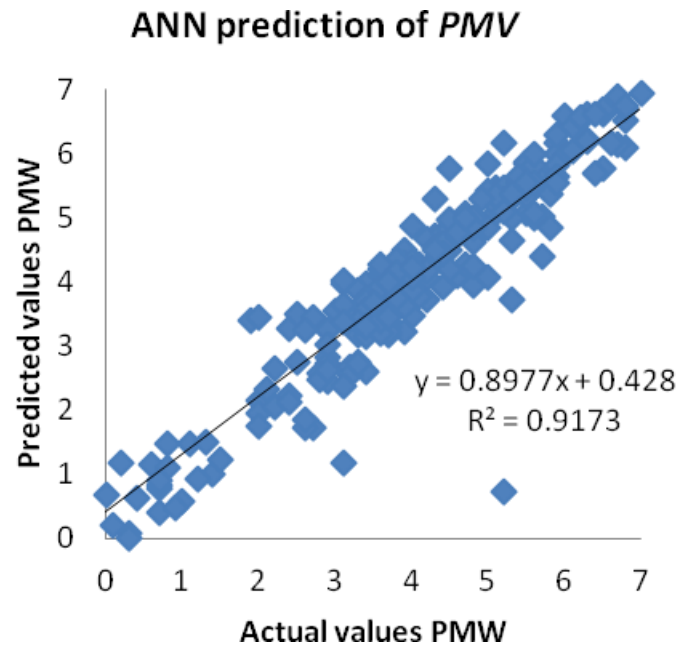

ANN prediction of $P E T$

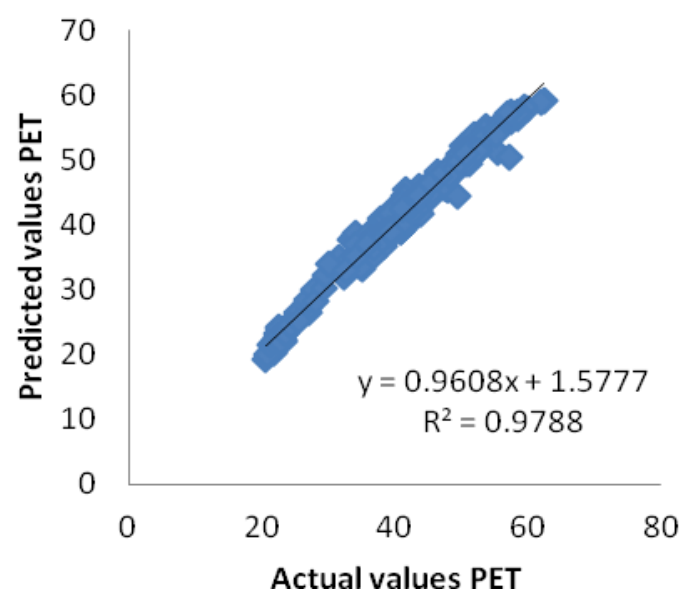

ANN prediction of SET

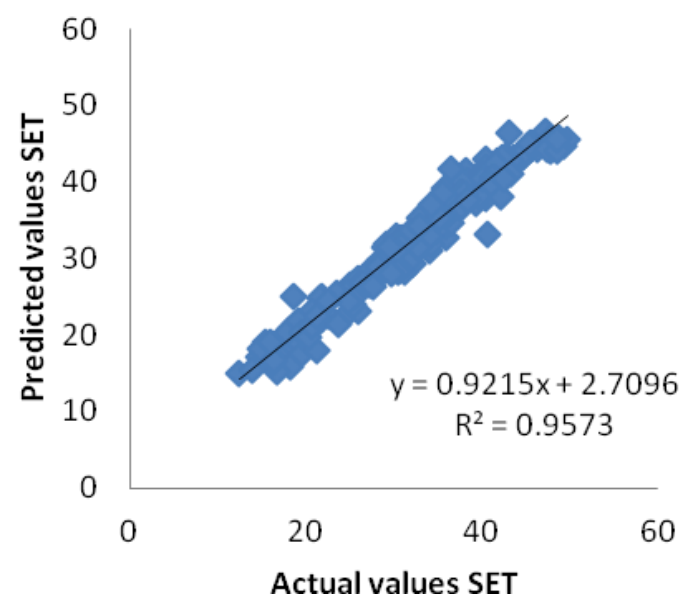

Figure 3. NN with BP predictive results for thermal comfort parameters

Slika 3. Neuronska mreža za BP principom za predikciju parametra termalnog komfora
Table 1. Predictive performances of the three methods

Tabela 1. Prediktivne performanse tri metode

\begin{tabular}{|c|c|c|c|c|}
\hline \multirow{4}{*}{ PMV } & & & & \\
\cline { 2 - 5 } & ELM & 0.4001 & 0.9603 & 0.9799 \\
\cline { 2 - 5 } & ANN & 0.5757 & 0.9173 & 0.9577 \\
\cline { 2 - 5 } & GP & 0.5751 & 0.9173 & 0.9577 \\
\hline \multirow{4}{*}{ PET } & & & & \\
\cline { 2 - 5 } & ELM & 0.8754 & 0.9915 & 0.9957 \\
\cline { 2 - 5 } & ANN & 1.3938 & 0.9788 & 0.9893 \\
\cline { 2 - 5 } & GP & 1.3938 & 0.9788 & 0.9893 \\
\hline \multirow{4}{*}{ SET } & & & & \\
\cline { 2 - 5 } & ELM & 1.3107 & 0.9744 & 0.9871 \\
\cline { 2 - 5 } & ANN & 1.7043 & 0.9573 & 0.9784 \\
\cline { 2 - 5 } & GP & 1.7534 & 0.9534 & 0.9764 \\
\hline
\end{tabular}

\section{CONCLUSION}

In the study a procedure is performed to make prediction of the thermal comfort of the visitors in open urban areas. The thermal comfort is presented with four output factors. Input factors are based on microclimatic conditions and a questionnaire survey. The visitors' responses are analysed based on their location, activity, gender, age and locality.

Computational intelligence approaches are used for the prediction of the thermal comfort. The approaches are based on neural networks and genetic programming principle. Neural network is trained with two training algorithm for comparative study. The training algorithm are extreme learning machine and back-propagation algorithm. Measurement is performed to acquire thermal conform input/output data pairs. The data is them used for the training and testing of the computational intelligence approaches. Based on prediction neural network with extreme learning machine shows the best predictive performances of the thermal comfort parameters.

\section{REFERENCES}

[1] S.Q. da Silveira Hirashima, A.Katzschner, D.G.Ferreira, E.S.de Assis, L.Katzschner (2016) Thermal comfort comparison and evaluation in different climates, Urban Climate, 23, 219-230.

[2] I.Karakounos, A.Dimoudi, S.Zoras (2018) The influence of bioclimatic urban redevelopment on outdoor thermal comfort, Energy and Buildings, 158, 1266-1274.

[3] C.Lamarca, J.Qüense, C.Henríquez (2016) Thermal comfort and urban canyons morphology in coastal temperate climate, Concepción, Chile, Urban Climate, 23, 159-172. 
[4] S.B.Ali, S.Patnaik (2017) Thermal comfort in urban open spaces: Objective assessment and subjective perception study in tropical city of Bhopal, India, Urban Climate, 24, 954-967.

[5] M.Taleghani, L.Kleerekoper, M.Tenpierik, A. van den Dobbelsteen (2015) Outdoor thermal comfort within five different urban forms in the Netherlands, Building and Environment, 83, 65-78.

[6] V.Cheng, E.Ng, C.Chan, B.Givoni (2012) Outdoor thermal comfort study in a sub-tropical climate: a longitudinal study based in Hong Kong International Journal of Biometeorology, 56, 43-56.

[7] L.Chen, E.Ng (2011) Outdoor thermal comfort and outdoor activities: A review of research in the past decade, Cities, 29, 118-125.

[8] [8] K.C.Parsons (2014) Human therma environments: the effects of hot, moderate, and old 8 on human health, comfort, and performance. CRC Press, p.635-657.

[9] K.Cenam R. de Dear (2001) Thermal comfort and behavioural strategies in office buildings located in a hot-arid climate, Journal of Thermal Biology, 26 , 409-414.

[10] B.Griefahn, C.Künemund (2001) The effects of gender, age, and fatigue on susceptibility to draft discomfort, Journal of Thermal Biology, 26, 395400.

[11] K.Nagashima, T.Yoda, T.Yagishita, A.Taniguchi, T.Hosono, K.Kanosue (2002) Thermal regulation and comfort during a mild-cold exposure in young Japanese women complaining of unusual coldness, Journal of applied physiology, 92, 1029-1035.

[12] S.Karjalainen (2007) Gender differences in thermal comfort and use of thermostats in everyday thermal environments, Building and Environment, 42, 15941603.

[13] M.Indraganti, K.D.Rao (2010) Effect of age, gender, economic group and tenure on thermal comfort: A field study in residential buildings in hot and dry climate with seasonal variations, Energy and Buildings, 42, 273-281.

[14] J.Nakano, S.Tanabe, K.Kimura (2002) Differences in perception of indoor environment between Japanese and non-Japanese workers, Energy and Buildings, 34, 615-621.

[15] M.A.Humphreys (1977) Clothing and the outdoor microclimate in summer, Building and Environment, 12(3), 137-142.

[16] H.B.Rijal (2012) Thermal Adaptation Outdoors and the Effect of Wind on Thermal Comfort, Ventilating Cities, p.33-58.

[17] F.Ali-Toudert, H.Mayer (2007) Effects of asymmetry, galleries, overhanging facades and vegetation on thermal comfort in urban street canyons, Solar Energy, 81, 742-754.

[18] F.Bourbia, H.B.Awbi (2004) Building cluster and shading in urban canyon for hot dry climate: Part 1 : Air and surface temperature measurements, Renewable energy, 29, 249-262.
[19] M.K.Singh, S.Mahapatra, S.K.Atreya (2011) Adaptive thermal comfort model for different climatic zones of North-East India, Applied Energy, 88(7), 2420-2428.

[20] V.Soebarto, H.Bennetts (2014) Thermal comfort and occupant responses during summer in a low to middle income housing development in South Australia, Building and Environment, 75, 19-29.

[21] K.Villadiego, M.A.Velay-Dabat (2014) Outdoor thermal comfort in a hot and humid climate of Colombia: A field study in Barranquilla, Building and Environment, 75, 142-152.

[22] S.Watanabe, K.Nagano, J.Ishii, T.Horikoshi (2014) Evaluation of outdoor thermal comfort in sunlight, building shade, and pergola shade during summer in a humid subtropical region, Building and Environment, 82, 556-565.

[23] H.Esen, M.Inalli, A.Sengur, M.Esen (2008) Modeling a ground-coupled heat pump system by a support vector machine, Renewable Energy, 33(8), 1814-1823.

[24] H.Esen, F.Ozgen, M.Esen, A. Sengur (2009) Modelling of a new solar air heater through leastsquares support vector machines, Expert Systems with Applications, 36(7), 10673-10682.

[25] H.Esen, M.Inalli, A.Sengur, M.Esen (2008) Artificial neural networks and adaptive neuro-fuzzy assessments for ground-coupled heat pump system, Energy and Buildings, 40(6), 1074-1083.

[26] [26]H.Esen, M.Inalli, A.Sengur, M.Esen (2008) Forecasting of a ground-coupled heat pump performance using neural networks with statistical data weighting pre-processing, International Journal of Thermal Sciences, 47(4), 431-441.

[27] H.Esen, M.Inalli, A.Sengur, M.Esen (2008) Performance prediction of a ground-coupled heat pump system using artificial neural networks, Expert Systems with Applications, 35(4), 1940-1948.

[28] H.Esen, F.Ozgen, M.Esen, A.Sengur (2009) Artificial neural network and wavelet neural network approaches for modelling of a solar air heater, Expert systems with applications, 36(8), 1124011248.

[29] I.Mansouri, M.Shariati, M.Safa, Z.Ibrahim M.M.Tahir, D.Petković (2017) Analysis of influential factors for predicting the shear strength of a $\mathrm{V}$ shaped angle shear connector in composite beams using an adaptive neuro-fuzzy technique, Journal of Intelligent Manufacturing, p.1-11.

[30] M.Mohammadhassani, H.Nezamabadi-Pour, M.Suhatril, M. Shariati (2014) An evolutionary fuzzy modelling approach and comparison of different methods for shear strength prediction of highstrength concrete beams without stirrups, Smart Structures and Systems, 14(5), 785-809.

[31] A.Toghroli, M.Mohammadhassani, M.Suhatril, M.Shariati, Z.Ibrahim (2014) Prediction of shear capacity of channel shear connectors using the ANFIS model, Steel and Composite Structures, 17(5), 623-639. 
[32] M.Safa, M.Shariati, Z.Ibrahim, A.Toghroli, S.B.Baharom, N.M.Nor, D.Petkovic (2016) Potential of adaptive neuro fuzzy inference system for evaluating the factors affecting steel-concrete composite beam's shear strength, Steel and Composite Structures, 21(3), 679-688.

[33] A.Matzarakis, F.Rutz, H.Mayer (2007) Modelling radiation fluxes in simple and complex environments-application of the RayMan model, International journal of biometeorology, 51(4), 323334.
[34] G.-B.Huang, Q.-Y.Zhu, C.-K.Siew (2004) Extreme Learning Machine: A New Learning Scheme of Feedforward Neural Networks, International Joint Conference on Neural Networks, 2, 985-990.

[35] D.Wang, G.-B.Huang (2005) Protein Sequence Classification Using Extreme Learning Machine, Proceedings of International Joint Conference on Neural Networks, 3, 1406- 1411.

[36] K.Hornik (1991) Approximation capabilities of multilayer feedforward networks, Neural Networks, 4, 251-257.

\section{IZVOD}

\section{PREDIKCIJA TERMALNOG KOMFORA U OTVORENIM URBANIM POVRŠINAMA}

Termalna osećajnost od strane posetilaca i turista je važan indicator za urbane površine na osnovi fizioloških, psiholoških i uslova ponašanja turista. Prema tome u ovom radu je analiziran termalni komfor posetilaca i turista u otvorednim urbanim površinama. Za tu svrhu su korišćeni fizički podaci kao anketa među turistima i posetiocima. Kako bi bili postignuti optimalni uslovi u otvorenim urbanism površinama potrebno je uraditi predikciju termalnog komfora $u$ tim površinama. Rezultati poredikcije se mogu potom koristiti za optimalni aranžman u otvorenim urbanism površinama. Rezultati su dobijeni pomoću tri metode. Te metode su bazirane na osnovu veštačke inteligencije.

Ključne reči: termalni komfor; urbana površina; neuronska mreža; mikroklima

Naucni rad

Rad primljen: 24. 08. 2018.

Rad prihvaćen: 12. 09. 2018.

Rad je dostupan na sajtu: www.idk.org.rs/casopis

(C) 2018 Authors. Published by Engineering Society for Corrosion. This article is an open access article distributed under the terms and conditions of the Creative Commons Attribution 4.0 International license (https://creativecommons.org/licenses/by/4.0/) 